This is the version of the article accepted for publication in Research in African Literatures published by Indiana University Press: http://www.jstor.org/journal/reseafrilite

Accepted version downloaded from SOAS Research Online: http://eprints.soas.ac.uk/22865/

\title{
Sci-fi and Afrofuturism in the Afrophone Novel: Writing the Future and the Possible in Swahili and in Shona
}

\section{Alena Rettová, SOAS, London}

\section{ABSTRACT}

The paper explores literary experimentation in novels in African languages, with a focus on Swahili and Shona science fiction and Afrofuturism. While science fiction is a genre whose relevance to Africa has often been questioned, Afrophone writers have produced sci-fi novels in several African languages and the genre seems to be experiencing a new interest in the 21 st century. A number of novels contain visions of Africa's utopian or dystopian futures and often suggest ways to construct this future or, indeed, reconstruct the present in view of the future. The look at Africa from its imagined future also stimulates a rethinking of narratives about Africa's past. The paper outlines the history of sci-fi and futuristic prose in Swahili and in Shona and analyses the textual strategies which these novels employ to "write the future and the possible."

\section{ACKNOWLEDGEMENTS}

I would like to thank Flora Veit-Wild and Clarissa Vierke, the two anonymous peer-reviewers, Anja Oed, Lutz Diegner, Jacob Mapara, and Benedetta Lanfranchi for their feedback, support and helpful suggestions. I would also like to thank Kevin Ochieng Okoth, Miriam Pahl, and Michelle Clarke for awakening me from a philosophical and literary "dogmatic slumber" and making me look in new directions.

La Vie est ailleurs. The title of Milan Kundera's famous novel suggests that truth can only be captured through its "other," its "elsewhere." The French word, ailleurs, evokes the locative meanings less strongly than either the original Czech (jinde) or the English (elsewhere). Its etymology, probably the Vulgar Latin *aliore, shortened from *in aliore loco ("in another place," Trésor), shows why this is the case: the "place" (loco, nominative locus) is not expressed on the surface. I would like to use this French word in this paper instead of an English equivalent when referring to the far-off universes of science fiction and Afrofuturism, be they remote in time or in 
This is the version of the article accepted for publication in Research in African Literatures published by Indiana University Press: http://www.jstor.org/journal/reseafrilite

Accepted version downloaded from SOAS Research Online: http://eprints.soas.ac.uk/22865/

space. The word will, in its meaning and its alienating, foreign form, evoke the necessity to first remove the illusory referent--the "actual world" or "objectivity"--if we wish to approximate "life." The genres of science fiction and Afrofuturism, exploring reality through unreality, exploit the potential of this ailleurs. They liberate language to speak to itself, to describe non-existent but possible worlds and make literature into an expression of human freedom; not of being slave to conventions, even if conscious of their conventionality.

This article examines literary experimentation in novels in African languages, with a focus on Swahili and Shona science fiction and Afrofuturism. It looks at how these literatures "write the possible and the future." While the future can be seen as one type of possibility and it is indeed the ideal screen to project possibilities and model alternative worlds, it has a different ontological status from the possible. In claiming to be an extension of the extra-textual reality that literature, in one way or another, writes about, it sustains a tighter link to the actual world than genres that project fantasy worlds in outer space or in an abstract imaginary space--even if these distinctions are, of course, largely neutralized in fictional literature.

But there is another reason why it is good to keep the future under the spotlight in African literature. Africa is often portrayed as a continent without a future, a continent of innocent ignorance about time, a place of a blissful, animal-like existence in the present; such is the basis of Hegel's dismissal of the continent as an actor in the world's history: "Africa . . . is the Unhistorical, Undeveloped Spirit, still involved in the conditions of mere nature" (Hegel 117). Hegel's reading of Africa was very influential in Europe's intellectual and political history, directly feeding into justifications of the colonial enterprise. Alternatively, Africa is depicted as a continent of the past, of perennial traditions that determine the present--and compromise the future. Such visions constitute a vein that goes through much of Africanist discourse: from cultural theory, built upon issues of identity and cultural essentialism, via politics, which oftentimes strives to resurrect a putative precolonial past, to philosophy. 
This is the version of the article accepted for publication in Research in African Literatures published by Indiana University Press: http://www.jstor.org/journal/reseafrilite

Accepted version downloaded from SOAS Research Online: http://eprints.soas.ac.uk/22865/

African philosophers such as John S. Mbiti have, notoriously, denied Africans the very capacity to conceive of a "distant future" (23) and found evidence of this in a range of African practices, down to the alleged grammatical incapacity of African languages to express the remote future. While Mbiti's arguments can easily be refuted, the point he made about Africans' lack of imagining the future is a complex one and it has been reasserted by other scholars. Johanna Offe confirms a glaring absence in Africa of the "modern" concept of "contingent, and yet controllable future" (56). This concept underlies the notion of development understood as readiness to alter one's current practices to change a future situation; for that the future situation must be imagined first--and it must be seen as determinable by human agency. If, as Offe suggests in line with Pierre Bourdieu, in Africa the future is conceptualized as an inescapable "unfolding" (Offe 62) of events that are taking place in the present, following from the present as its logical consequence, and it is "not contingent and open" (63) with "various [possible] outcomes" (62), but rather "expected and certain" (63), then of course the continent is locked in an eternal cyclical return of the same. The future only regurgitates the past and it is meaningless to make it the object of imagination, because it is simply an extension of the present and past situation.

The critical importance of imagining the future is well expressed in the theory surrounding the concept of Afrofuturism. The definitions of Afrofuturism vary, but all of them stress the connection of the imagination of the future with the lives of black people. Many authors exclusively associate this trend with the African Diaspora and emphasize the dimension of race in the concept. According to Lisa Yaszek, "Afrofuturism appropriates the narrative techniques of science fiction to put a black face on the future" ("An Afrofuturist Reading" 297), and she connects the concept to the "150 years old tradition" ("Race" 1) of writing by African diasporic writers. However, the seminal article by Ghanaian/British art theorist Kodwo Eshun allows for a more inclusive reading of the concept, involving Africans and the continent itself. For Eshun, the basis of Afrofuturism is a concern about the dystopian representations of Africa's future: 
This is the version of the article accepted for publication in Research in African Literatures published by Indiana University Press: http://www.jstor.org/journal/reseafrilite

Accepted version downloaded from SOAS Research Online: http://eprints.soas.ac.uk/22865/

Afrofuturism's first priority is to recognize that Africa increasingly exists as the object of futurist projection. African social reality is overdetermined by intimidating global scenarios, doomsday economic projections, weather predictions, medical reports on AIDS, and lifeexpectancy forecasts, all of which predict decades of immiserization. ... Africa is always the zone of the absolute dystopia. (291-292)

Imaginations of the future are highly relevant because " $[t]$ he powerful employ futurists and draw power from the futures they endorse, thereby condemning the disempowered to live in the past" (289). Eshun elucidates that the future exists, on the one hand, "in mathematical formalizations such as computer simulations, economic projections, weather reports, futures trading, think-tank reports, consultancy papers" (290), and on the other hand, "through informal descriptions such as sciencefiction cinema, science-fiction novels, sonic fictions, religious prophecy, and venture capital” (290).

On account of this ubiquitous reference to the future and its political, social and commercial relevance, Eshun speaks of "the futures industry," which he defines as "the intersecting industries of technoscience, fictional media, technological projection, and market prediction" (290). This explains the critical importance of genres such as science fiction. Being part of "the futures industry," science fiction is "neither forward-looking nor utopian" but "a means through which to preprogram the present" (290): "science fiction was never concerned with the future, but rather with engineering feedback between its preferred future and its becoming present" (290). Afrofuturism "studies the appeals that black artists, musicians, critics, and writers have made to the future, in moments where any future was made difficult for them to imagine" (Eshun 294) and it strives to intervene in the dystopian projections regarding Africa and regain control over views of Africa's future, through an examination of "extraterrestriality, futurology, and techno-science fictions" (Eshun 293). 
This is the version of the article accepted for publication in Research in African Literatures published by Indiana University Press: http://www.jstor.org/journal/reseafrilite

Accepted version downloaded from SOAS Research Online: http://eprints.soas.ac.uk/22865/

Afrofuturism is a sub-genre of science fiction, a genre which is experiencing a boom in the present times in African Anglophone and Francophone literature, not least because of a concerted effort to redefine categories of literary criticism. Applying the label "science fiction" to African fiction is not a neutral act. Mark Bould speaks of African science fiction's being a “temporary, flexible, non-monolithic, and, above all, strategic identity" (“African” 11, emphasis added). He notes the fact that a lot of African sci-fi and futuristic writing has often been debated

in critical volumes which would never dream of using the term, or would at least prefer not to, deploying instead a de-science-fictionalized discourse of utopia and dystopia, and labelling anything irreal as some kind of postcolonial magic realism or avant-gardist experimentalism. (“African” 13)

As Lydia Moudileno observes in her analysis of Sony Labou Tansi's La Vie et demi, literary critics' "exclusive focus on magical realism at the expense of other, perhaps more significant, literary traditions (such as science fiction) constitutes a problematic misreading of the novel" (28). Nonrealist African fiction tends to be read through the theoretical lenses of magical realism, often aided by a "hermeneutics of vagueness" (Warnes 1) to define the concept. Celebrated as it is, magical realism makes critics look for influences of the past. It strives to establish connections with "precolonial” African realities and thought systems, African myths and folklore--with nostalgia for the "origins." Contrary to this, the conceptual frameworks of sci-fi and (Afro)futurism imagine the present and past from within a future perspective. The future is malleable, changeable; its imagination is coextensive with human freedom: "Afrofuturism gives a central role to human agency and free will" (Okoth 7). On account of this, writing the future also has an effect on how the present and the past are crafted: "both past and future can be recontextualised in a way that changes the present" (Okoth 7). Sci-fi and Afrofuturism command freedom in reimagining Africa and 
This is the version of the article accepted for publication in Research in African Literatures published by Indiana University Press: http://www.jstor.org/journal/reseafrilite

Accepted version downloaded from SOAS Research Online: http://eprints.soas.ac.uk/22865/

reinventing African identities. These trends have the amazing power to reprogram perceptions of the African present and reconfigure the narratives of Africa's past: "Just as the right words and actions can speak the future into existence, the same can recast the past, too" (Womack 153).

Both Afrofuturism and sci-fi have the capacity to imagine Africa's ailleurs. Some works deal with the future and project an alternative reality there while others introduce advanced technology and construct an alternative reality in outer space, on another planet. A number of novels contain visions of Africa's utopian or dystopian futures and often suggest ways to construct this future or, indeed, reconstruct the present in view of the future. The future world or the world in outer space--a world ailleurs--can be a projection and construction of an ideal society. The ailleurs can also be created for reasons only indirectly related to the actual world, for example, to project a philosophical utopia.

The label of Afrofuturism or futurism has never been systematically applied to novels in African languages, except for a recent article by Mikhail Gromov, who associates the developments in the domain of the Swahili novel with "futuristic visions" ("Visions" 45); the forthcoming volume edited by Clarissa Vierke and Katharina Greven, entitled Dunia Yao: Utopia/Dystopia in Swahili Fiction, goes a long way in rectifying the situation.

Again, with the exception of Gromov, who speaks of "science-fiction--or . . . anti-utopia" as one stylistic level of Nagona and Mzingile ("Nagona" 75), there seems to be a nearly systematic avoidance of the label "sci-fi." The very unambiguous sci-fi Walenisi is called "novel-as-parable" (57) and "parabolic and introspective novel" (474) in Bertoncini et al.'s magisterial Outline of Swahili Literature, merely with a concession of "science fiction motifs" (474). Elena BertonciniZúbková also mentions the "enormous science-fiction-like castle" in Babu Alipofufuka ("When" 25), which is a narrative that could itself be characterized as sci-fi or futuristic. In these characterizations, sci-fi elements are engaged within a broader pattern (e.g. parable); of course, such a reading is not 
This is the version of the article accepted for publication in Research in African Literatures published by Indiana University Press: http://www.jstor.org/journal/reseafrilite

Accepted version downloaded from SOAS Research Online: http://eprints.soas.ac.uk/22865/

wrong, but calling the novels simply "sci-fi" would foreground the potential of futuristic or "ailleuristic" imagination.

This reluctance to speak of sci-fi also holds true for literatures in other African languages. The debate about an early sci-fi novel in Hausa, Tauraruwa Mai Wutsiya (The Comet, 1969) by Umaru Dembo, is telling in this respect. The novel describes a trip to outer space undertaken by a boy called Kilba with an extraterrestrial guest called Kolin Koliyo. The two "land on the star of Auriya, which is inhabited by little people with elastic bodies" (Piłaszewicz 225). Stanisław Piłaszewicz (225) calls the novel "a new type of novel" where "fabulous themes and the realities of African life are mixed up with naïve science fiction." Graham Furniss notes that "the story displays the influence of news of spaceflights and the training and activities of astronauts, but whether this marks a new departure in the novel is debatable" (37). Instead of the novel's prominent sci-fi storyline Furniss lists the novel's "mixture of cultural influences . . . from Indian cinema to Western science to Islamic religious beliefs" and insists on the "familiar" elements of the story, including "the journey ...; the transition from reality to fantasy, with jinn replaced by extra-terrestrial beings ...; and the hero's survival through tests and dangers" (37). In other words, the innovative plot is reduced to a variation of well-established tropes and techniques of Hausa writing and its sci-fi dimension is removed altogether; the sci-fi elements are reinterpreted as a mere "replacement" of more traditional themes and motifs and the potential of the novel's being "a new departure" is neutralized.

The recent developments in the Swahili novel have been approached through concepts such as "experimental," "postmodernist," "allegoric," "esoteric," "polymorphic," and "anti-novel" (Bertoncini-Zúbková et al. 125), some critics speak of the "new novel” (Gromov, "Visions" 40) or riwaya mpya (Mwangi 1 and Wamitila, Kamusi 180-181, where he identifies riwaya mpya and riwaya ya kimajaribio, "experimental novel"). ${ }^{1}$ The novels have been read through the lenses of “postmodernism" (Gromov, "Postmodernistic," 28; Aielo Traore 20), “existentialism” or udhanaishi 
This is the version of the article accepted for publication in Research in African Literatures published by Indiana University Press: http://www.jstor.org/journal/reseafrilite

Accepted version downloaded from SOAS Research Online: http://eprints.soas.ac.uk/22865/

(Diegner, "Intertextuality" 29; Wamitila, Uhakiki 121), or, most frequently, "magic(al) realism” (e.g. Khamis, "Fragmentation" 78).

Reading these novels through the lenses of sci-fi and Afrofuturism is nothing short of a revelation. While an orientation towards magical realism prioritizes the "folkloristic plan" (Gromov, "Nagona" 74) and the "mythological concepts and plots" (Khamis, "Fragmentation" 86) in these narratives, and thus perpetuates a traditionalistic and past-oriented perspective on Africa, a sci-fi or futuristic reading opens up a perspective on Africa as a modern, vibrant continent, which is--through its incisive literary response to scientific and technological progress and its futuristic imagination-fully "plugged" in important discussions and vitally connected with the future not only of Africa but indeed of the planet--and beyond, the entire universe.

\section{AFROPHONE SCI-FI AND FUTURISM}

This article looks at literatures in two African languages, Swahili and Shona. A plurality of literary traditions is hiding behind these two languages; even a single language may be an umbrella for distinct literary traditions shaped by specific political, historical and cultural contexts. In his recent text on the Swahili "new novel," Gromov makes a distinction between Kenyan and Tanzanian authors, concluding that, while there are similarities between novels from the two countries, there are also significant differences on the symbolic level. The Kenyan novels "represent in a rather recognisable way modern political reality, with the purpose of providing a satirical portrayal of this reality" ("Local Achievements" 65); on the other hand, "in the novels by Tanzanian authors characters and events have at least several levels of meaning" ("Local Achievements" 65). There is hardly a single Swahili literature. In addition to Kenya and (continental) Tanzania, Zanzibar represents a separate culture which has produced a distinct literary tradition, and additionally, many authors labeled as Tanzanians or Kenyans are cosmopolitans, living or having lived outside of their 
This is the version of the article accepted for publication in Research in African Literatures published by Indiana University Press: http://www.jstor.org/journal/reseafrilite

Accepted version downloaded from SOAS Research Online: http://eprints.soas.ac.uk/22865/

countries of origin (for instance, Kezilahabi has lived in the U.S. and now lives in Botswana, Said

Ahmed Mohamed has lived in Japan and in Germany, Wamitila has lived in Germany). Yet, language provides a platform for interaction and inclusion--all the Swahili "literatures" have been studied together and described in a shared body of secondary literature--, and therefore the linguistic criterion is a largely valid basis for classification, even for making general judgments. This is somewhat different for Zimbabwean writers. Many live in exile and many also publish in both English and Shona. There is thus a common ground for the study of Zimbabwean literature--the country and its history--which is home to a multilingual literary tradition in English, Shona, Ndebele, and marginally also other African languages.

The connection between Swahili and Shona literatures is typological; there is no causal relationship in the sense of cultural influence or adaptation between the two literatures. Shona joins Swahili as one of the few African languages that have stepped onto the terrain of novelistic experimentation and assumed the implications of such "departures from realism" (Vierke and Greven 18). Unlike the Lingala, Wolof, or Gikuyu "isolated ventures by individual authors" (Rettová, "Novel" 84), Shona literary experimentation falls back on a rich and well-documented history of novelistic writing; a tradition of literary experimentation has established itself. In this way the developments in Shona literature bear resemblance to those in Swahili although the pathways literary experimentation has followed in each literature are different and impacted by the specific conditions of each culture. Swahili literature, in particular, has been extensively debated by scholars; in recent years the "new novel" has become the object of a true mushrooming of critical literature. This article avoids rehearsing the findings of this literature, but it takes special care to reference these sources.

In Swahili prose fiction the descriptions of ailleurs started with the initiator of the Swahili novel, Shaaban Robert, and his Kusadikika (1951, "Believable") and Kufikirika ("Thinkable, Imaginable," written as early as 1946, but only published posthumously in 1967). The titles refer to the names of imaginary countries in which the plots are set. The two novels use the device of a 
This is the version of the article accepted for publication in Research in African Literatures published by Indiana University Press: http://www.jstor.org/journal/reseafrilite

Accepted version downloaded from SOAS Research Online: http://eprints.soas.ac.uk/22865/

distant world to discuss a "diversity of sociopolitical themes" (Khamis, "Classicism" 57), in particular "issues of good governance and the rule of law" and "wisdom" (Topan 108). The characters in the novels are given allegorical names and, as Topan clarifies, "Robert deliberately draws his characters as stereotypes so as to create a milieu in which the focus is on the message, or the issues, in the novel" (109). Topan speculates that the reason why Robert chose an allegorical narrative is the censorship imposed on him in the Tanganyika of the colonial period, but he also connects the allegorical narrative with "the Swahili tradition of setting and uncovering fumbo ('hidden messages')” (Topan 110).

The Swahili experimental novel is a confluence of several literary traditions, each with specific features. The term "experimental novel" is adopted here in a meaning co-extensive with that of "speculative fiction," as a term which "encompasses genres as diverse as 'hard' science fiction, fantasy, horror, alternative history and magic realism" (Peterson 211). Experimentation with the representation of reality in these novels is indeed the salient feature of these novels, contrasted with literary realism. It is a feature Swahili literature shares with a large body of postcolonial literature which "celebrate[s] the use of anti-realist, 'postmodern' techniques and themes" (Cornillie 5). Gaylard employs the concept of "defamiliarization," which he identifies as "perhaps the overarching feature and technique of postcolonialist poetics, as it disrupts orthodox referentiality, making language more resonant, and generates referents beyond the empirical” (72). In distinction to the Russian formalists (Viktor Shklovsky) who introduced the concept, Gaylard, as the quotation shows, understands defamiliarization as a technique of distancing the narrative from a realistic depiction as the "norm" of literary writing. In departing from "the real"--and its representations--the meaning of literary experimentation is to test the limits of the possible, to imagine the future or the possible, to question the limits of the given. The imagination of an African ailleurs triggers, in addition, an imaginary reconstruction of the African present and past. 
This is the version of the article accepted for publication in Research in African Literatures published by Indiana University Press: http://www.jstor.org/journal/reseafrilite

Accepted version downloaded from SOAS Research Online: http://eprints.soas.ac.uk/22865/

In his Ziraili na Zirani (Azrael and Zirani, 1999, transl. as Pilgrims from Hell, 2006, by

Mkufya), William Mkufya pays homage to Shaaban Robert's Kufikirika through the magical formula Akirikifuk, which has the power to transform ideal entities such as devils into material beings. The manuscript of this book was first sent to a potential publisher in 1981 (Mkufya 37; the typescript of this first version of the novel by William Mkufya is dated 1980), but the novel only was published in 1999.

A major influence on the Swahili novel, both in Tanzania and in Kenya, is Euphrase Kezilahabi’s novelistic dilogy Nagona (proper name) and Mzingile (Labyrinth), published respectively in 1990 and 1991. An equally important influence, a Kenyan origin of the Swahili experimental novel, is Katama Mkangi's sci-fi novel Walenisi (Those-Are-Us, 1995). Other novels usually considered under the umbrella of "the experimental novel" are Kyallo W. Wamitila's BinaAdamu! (Man!, 2002) and Musaleo! (Neo-Moses!, 2004), and Tom Olali's Mafamba (Underhand Dealings, 2008), Watu wa Gehenna (People of Hell, 2012), as well as his two forthcoming works, Mashetani wa Alepo (Devils from Aleppo) and Barua ya Methodia (Methodia's Letter) ("Some Say" no page), and Said Ahmed Mohamed's Babu Alipofufuka (When Grandfather Came Back to Life, 2001) and Dunia Yao (Their World, 2006). Several novels in Swahili could be qualified as horror novels, such as Emmanuel Mbogo's Vipuli vya Figo (Kidney Transplants, 1996) and Gabriel Ruhumbika’s Janga Sugu la Wazawa (The Persistent Calamity of the Native Population, 2002), which presents an alternative history narrative.

Not all of these experimental novels qualify as sci-fi or Afrofuturism, but many do. Walenisi and Mafamba are set in outer space on different planets, and Babu Alipofufuka, Mafamba, and Watu wa Gehenna are set in the future (mid-21st and 25th centuries). Nagona, Mzingile, Bina-Adamu! and Musa-Leo! are works of speculative fiction situated in sketchy worlds and with meandering plots. Nagona and Mzingile construct an abstract, conceptual future, not expressed in terms of a numerical 
This is the version of the article accepted for publication in Research in African Literatures published by Indiana University Press: http://www.jstor.org/journal/reseafrilite

Accepted version downloaded from SOAS Research Online: http://eprints.soas.ac.uk/22865/

calendar but rather as a philosophically defined future. In Ziraili na Zirani angels create a new world after the destruction of the actual world.

The Shona experimental novel is the culmination of a development described by George Kahari in his The Rise of the Shona Novel. Kahari distinguishes three categories of Shona novels, A, B, and C. While category C comprises "Old World narratives," i.e. novels that deal with an imagined precolonial reality, categories A and B contain "New World novels," written in a realist style and introducing new narrative techniques. Category A contains the most innovative novels in Shona to date, in terms of style and narrative techniques. Kahari, whose research ends in 1984, includes three novels in this category: Thompson Tsodzo's Pafunge (Think About It, 1972), Charles Mungoshi's Ndiko Kupindana Kwamazuva (As Time Passes, 1975) and Kunyarara Hakusi Kutaura? (Is Silence Not Also Speech? 1983). Reviewing the situation of the Shona novel exactly twenty years after Kahari, at the 8th International Janheinz Jahn Symposium on African Literatures in 2004, Memory Chirere characterizes three other novels after these three as innovative: Raymond Choto's Tongoona (We Just Watch, 1990), Vitalis Nyawaranda’s Barika Remashefu (Bosses’ Wives, 1991), and Ignatius T. Mabasa’s Mapenzi (Lunatics, 1999). These recent Shona novels are praised for "structural and stylistic innovation" (Chirere 221). Mabasa published two other novels after Mapenzi, Ndafa Here? (Am I dead? 2008), and Imbwa Yemunhu (Man Dog, 2013).

While Mabasa's novels are highly innovative in terms of language and style and Mapenzi, in particular, also in using the device of a "mad" narrator and dissolving epistemological clarity in this way, a single author so far has established himself as a writer of "ontological experimentation" (Rettová, Afrophone Philosophies 286) in the genres of sci-fi and horror, Masimba Musodza, who is a Zimbabwean resident in the UK. His MunaHacha Maive Nei? (What Was In the Hacha River?), published in 2011 as an Amazon Kindle e-book and a year later in a book form, was marketed as "the definitive first science-fiction/horror novel in ChiShona and the first in that language to be available on amazon [sic] Kindle" (Stephen). Shavi Rechikadzi (Possessed by a Female Alien Spirit) 
This is the version of the article accepted for publication in Research in African Literatures published by Indiana University Press: http://www.jstor.org/journal/reseafrilite

Accepted version downloaded from SOAS Research Online: http://eprints.soas.ac.uk/22865/

followed in 2015, presented as a "tale of sexual violence, corruption in high places, a failed justice . . . and an unspeakable demonic power summoned to wreak a terrible vengeance" authored by "the master of the horror novel in ChiShona language" (cover of the book with a blurb in Shona and this shorter one in English). MunaHacha Maive Nei? has been mentioned in Mark Bould's survey of African science fiction as "the first sf novel published in the Bantu language chiShona" ("Africa SF" 11), but Musodza also calls it a "horror" (Musodza, "Interview" no page). It employs sci-fi elements built upon a conspiracy narrative critical of the detrimental influence of neo-colonial control over African countries and the ecological damage which ensues from it.

As this survey shows, novelistic literary experimentation constitutes a distinct phase of the histories of Swahili and Shona literatures, although it is a phase which is quite limited in terms of the quantity of authors and works. This fiction is also limited in terms of appreciation by readerships in their respective languages, as testified by reviews of these works by local literary critics. To name just two examples, Nagona and Mzingile have been regarded as "texts that impede Swahili literature" (Mwenda Mbatiah, quoted in Tchokothe, Transgression 141) while Mabasa has been accused of "assassinating our beautiful language" (John Gambanga, quoted in Chirere 223). The following sections compare three ways of "writing the future and the possible" in such recent Swahili and Shona "fiction that challenges the customary ontological boundaries of a hitherto 'broadly' realist mainstream tradition" (Khamis, "Signs" 92).

\section{AILLEURS AS ALLEGORY}

The future and the possible can be used used in contrast with the present, to castigate and/or transform the present: 
This is the version of the article accepted for publication in Research in African Literatures published by Indiana University Press: http://www.jstor.org/journal/reseafrilite

Accepted version downloaded from SOAS Research Online: http://eprints.soas.ac.uk/22865/

Science fiction writers can use its imaginative possibilities to hypothesize worlds where existing social problems have been solved; they can also imagine a future where the problems have been magnified or extended onto a grim dystopia. (Leonard 253)

This is the case of a number of several sci-fi novels, such as Mkangi's Walenisi and Olali's Mafamba, but also in futuristic works like Mohamed's Babu Alipofufuka and Olali's Watu wa Gehenna. They employ a distinct stylistic strategy to convey their socio-political message.

These sci-fi and futuristic works use descriptive realism: the novels use the realist style in their detailed descriptions of characters and settings, but they do not share the ontological and epistemological premises of literary realism about the extra-linguistic referent of fiction. They do not rely on realism as "the assumption that it is possible, through the act of representation, in one semiotic code or another, to provide cognitive as well as imaginative access to a material, historical reality that, though irreducibly mediated by human consciousness, and of course by language, is nonetheless independent of it" (Beaumont 2). Sci-fi novels are clearly not "realist" in this sense, but they tap into the narrative techniques of realism for their descriptions.

As a literary style such descriptive realism warrants an almost cinematographic plasticity of depiction. This is a frequent stylistic feature of "the imagination of the possible ... which emphasises the visual ... to produce a sense of the possible" (Vierke and Greven 15). Writers draw "tableau-like scenes," because "the visual presentation of scenes and sceneries . . gains prominence in utopian and dystopian literatures" (Vierke 74). In the sci-fi and futuristic novels such realistic depictions follow upon a shift to an ailleurs--to far-off locations or times. Space and time play a similar role in these novels: the temporal or spatial remoteness distances the fictional universe from the actual world enough to make possible the construction of a coherent reality and conjures up a new world while, at the same time, liberating the narrative from being an account of experience. 
This is the version of the article accepted for publication in Research in African Literatures published by Indiana University Press: http://www.jstor.org/journal/reseafrilite

Accepted version downloaded from SOAS Research Online: http://eprints.soas.ac.uk/22865/

This shift operates as a device which makes possible the reinterpretation of the fictional universe as an allegory referring to the actual world of experience. For this to take place, however, the text must establish nexuses between the narrative and reality. These nodal points of connections are built through a skillful manipulation of language. Through acronyms, anagrams and allegorical names of characters and settings, these novels establish firm connections with realities in the actual world.

In Katama Mkangi's Walenisi the very travel to outer space is marked by milestones with allegorical names. The protagonist, Dzombo, is driving a spaceship dodging rocks with names such as Jabali la Ujinga "Rock of Ignorance" (13), Jabali la Magonjwa "Rock of Sickness" (23), Jabali la Udhalimu "Rock of Oppression" (32), and so on. Having successfully navigated through these rocks, he arrives on a planet with an ideal, communist political arrangement, where "all inhabitants live in peace and love" (Bertoncini-Zúbková, "Kenyan” 45). This political system has followed upon a system of a tyrannical rule of the Wachuna--itself a political situation that reminds Dzombo of his home country. In this way, the allegorical narrative is a way to "handle political themes" (Wamitila, “Reading” 121).

Tom Olali's novels use the same device to reattach the extraterrestrial world back to the actual world. Mafamba describes a remote future (around 2500) as a competition between several planets and their leaders. The planet that is the main setting of the novel is called NUKA, and its history dates back to the creation of the world:

NUKA ilikuwa sayari ya zamani sana. Muumba alipoiumba KARIFA, sayari ya NUKA iliumbwa yapata miaka 4000 iliyopita. Sayari nyingi ziliundwa kama vile NUZAPIFU, NUTA na ELIMO-FR. Katika sayari zote hizi, iliyojulikana sana ni NUKA. Zamani sana ilijulikana kama NUKIA. (Mafamba 7) 
This is the version of the article accepted for publication in Research in African Literatures published by Indiana University Press: http://www.jstor.org/journal/reseafrilite

Accepted version downloaded from SOAS Research Online: http://eprints.soas.ac.uk/22865/

NUKA was a very old planet. When the Creator created KARIFA, the planet of NUKA was created, around 4000 years ago. Many other planets were created, such as NUZAPIFU,

NUTA and ELIMO-FR. Among all these planets, NUKA was the most well-known. In the past it was known as NUKIA.

The capital letters form words that are scrambled letters of acronyms of political parties and places: AFRIKA, KANU, TANU, FRELIMO, ZANU-PF, with additional meanings attached to them in these anagrams: while NUKIA means "smell sweet," NUKA means "smell bad." NUKA is then described in terms of its neighboring planets, from which originate some of the beings (Maotad, Limioe, and Amrao) that compete for planetary rule:

Amrao aliteleza kutoka sayari ya DiPieLi. Aliamini kuwa sayari ya DiPieLi ilikuwa ni sayari nzuri ikilinganishwa na sayari nyingine yoyote. Amrao awali alikuwa ameteleza kutoka sayari nyingine--Ile ya DiPieNi. DiPieLi na DiPieNi ni sayari mbili ambazo zilipakana na sayari ya PiDi. (Mafamba 6)

Amrao slipped from the planet DiPieLi. He believed that the planet DiPieLi was better than any other planet. Amrao had originally slipped from another planet--that of DiPieNi. DiPieLi and DiPieNi are two planets neighboring upon the planet of PiDi.

Gromov suggests that in Maotad, Limioe, and Amrao "a reader can very easily recognize the three key figures of Kenya's recent political history: Daniel arap Moi, Mwai Kibaki and Raila Odinga" ("Visions" 47) and qualifies Mafamba as "a rather thinly disguised political satire" ("Visions" 47). Clearly, NUKA's neighboring planets are also political parties led by these politicians: Liberal Democratic Party (LDP), National Democratic Party (NDP), and Democratic Party (DP). 
This is the version of the article accepted for publication in Research in African Literatures published by Indiana University Press: http://www.jstor.org/journal/reseafrilite

Accepted version downloaded from SOAS Research Online: http://eprints.soas.ac.uk/22865/

Olali's Watu wa Gehenna describes a futuristic landscape where the devil rules over Kiafra (metathesis of “Afrika”), aided by Afisul ("Lusifa," i.e. Lucifer). Hell itself is situated inside mountains bearing names such as Korrapzion or Traibbolizim. This play with language signals the nodal points of connection to the actual world and a way to read the novel as an allegory.

While presenting much sketchier fictional worlds (absence of descriptive realism) which are not situated in the future or in outer space, Wamitila's Bina-Adamu! and Musaleo! employ the same techniques: play with language creates a nexus to the real world and suggests a reading of the unfamiliar setting, character or episode as an allegory.

Walenisi, Mafamba and Watu wa Gehenna effectuate a shift to another world, situated elsewhere or in the future. In this world ailleurs, descriptive realism is used to provide cinematographic plasticity of depiction. At the same time, these novels keep a firm link to the actual world through a play on words which highlights the allegorical nature of the whole narrative about the future or about outer space. Allegorical names, scrambled acronyms and other puns establish nexus points where the writers effectuate a disruption of the "reality effect" (Barthes 141) evoked for the ailleurs through its plastic descriptions and enforce a return to the actual world, in establishing familiarity with the actual world.

For instance, Dzombo's space travel towards the planet Walenisi passes through the dangerous asteroid belt. His spacecraft has automatic control, robots, buttons and levers, he experiences gravity overload during take-off and acceleration and then weightlessness as in real space travel (descriptive realism). But the rocks he dodges on his way are called "Rock of Ignorance," "Rock of Sickness," or "Rock of Oppression," and these names signal that Dzombo is not traveling in the actual cosmos (disruption of the "reality effect"), but that his travel is in fact an allegory of avoiding ignorance, disease, and oppression in order to find a perfect society (return to the actual world). The names of the asteroids refer to realities known from the actual world 
This is the version of the article accepted for publication in Research in African Literatures published by Indiana University Press: http://www.jstor.org/journal/reseafrilite

Accepted version downloaded from SOAS Research Online: http://eprints.soas.ac.uk/22865/

(establishing familiarity with the actual world), and the selection of these obstacles (human weaknesses and interpersonal conflicts) gives the allegorical journey an eminently political meaning.

Language referentiality is challenged through the shift to ailleurs, creating semantic vacancies (expressions without real-world referents, such as the specific asteroids Dzombo dodges). However, these are not used to explore the possible (for example, to imagine extra-terrestrial asteroids) but endowed with allegorical meanings which reattach the narrative to the actual world. Such sci-fi and futuristic narratives are employed by their authors to present critiques of contemporary politics, an intention clearly present in these novels. These non-realist narratives are therefore not written for the sake of pure exploration of the unknown, the possible, or the future, but as a political commentary on the actual world.

Said Ahmed Mohamed's futuristic prose shares many qualities with the novels by Mkangi, Wamitila, and Olali, both in the way he uses language and in the clear presentation of "political reality" (Gromov, "Local Achievements" 65). The exuberant neologisms, the unusual names of persons, objects, and places stand for recognizable social and political realities while the futuristic setting is a device to criticize the Global North's exploitative handling of the Third World and Africans' co-option in the process. The novels are allegories of neo-colonialism, corruption, and cultural and generational alienation.

For novels such as Walenisi, Mafamba, Watu wa Gehenna, Bina-Adamu!, Musaleo! as well as for Babu Alipofufuka and Dunia Yao, the ailleurs is a device to criticize the actual world. This type of speculative fiction remains mimetic of the actual world, attached to it through allegory or through the postulate of mimesis: of speculative fiction imitating the complexity of the postcolonial world through the complexity of style. Through allegorical employment of sci-fi and futuristic narratives and through reinforcing the postulate of mimesis, these novels fall short of "writing the possible." They are foregoing the opportunity to conjure up the possible in descriptions of (spatial or temporal) ailleurs and to use ailleurs as a backdrop on which to paint an imagined future. However, 
This is the version of the article accepted for publication in Research in African Literatures published by Indiana University Press: http://www.jstor.org/journal/reseafrilite

Accepted version downloaded from SOAS Research Online: http://eprints.soas.ac.uk/22865/

some of the allegorical narratives do project alternatives to reality--often ideal worlds built upon utopian philosophies. Such is the case of Walenisi, which projects a utopian society based on communist principles. This notwithstanding, most of the novels are about the actual, present world and criticize conditions in the actual world. Despite the temporal or spatial distance, Mafamba, Watu wa Gehenna or Babu Alipofufuka are describing present or past reality. This raises the question of the meaning of stylistic "defamiliarization": is it a simple cover for political satire or can it mediate something else?

\section{CONCEPTUAL FUTURES}

Critics emphasize the philosophical orientation of Kezilahabi's "bundle of enigmas" (Tchokothe, Transgression 102), the two short novels Nagona and Mzingile. Wamitila calls them "Kezilahabi's Metaphysics" (title of article) and "Kezilahabi's philosophy" (“A Philosophical Labyrinth" 79); he repeatedly emphasizes their "occupation with the philosophical" ("Contemptus" 16). Diegner comments on the novels" "philosophical sophistication" ("Bwanamvinyo" 107). Coughlin affirms that they are "above all, a vehicle for Kezilahabi's philosophical musings" (3). The novels describe a destruction of the human world and its reconstruction in a post-apocalyptic world. This "new world" (Mezger 81) is not connected to the world that precedes it by dates; it is a conceptual future, a newly constructed reality characterized by a radical rupture from the previous one.

In his doctoral thesis of 1985, Kezilahabi presents a profound reflection on the meaning of African literature and literary criticism. Rebeling against the "prevailing tendency among literary critics to read African literature against formal and aesthetic paradigms deeply rooted in the Western literary and philosophical traditions" (Lanfranchi 72), he insists on "the importance of approaching literary production from within the artistic and philosophical tradition it stems from" (Lanfranchi 72). The chief ailment of this adoption of foreign aesthetic criteria and philosophical procedures is 
This is the version of the article accepted for publication in Research in African Literatures published by Indiana University Press: http://www.jstor.org/journal/reseafrilite

Accepted version downloaded from SOAS Research Online: http://eprints.soas.ac.uk/22865/

what he calls "the tragic epistemology of Western man" (Kezilahabi, "African" 219), namely the split of reality into "the categories of Subject/Object" (215). Its manifestation in literature is an understanding of literature as representation; an understanding that enables African experience to be "objectified and reduced to a body of knowledge that signifies" (194). Objecting to this view, Kezilahabi advocates for a "dismantl[ing of] the resemblance of language to the world" (216).

This view can be read as a call to disrupt literary realism. This is, indeed, implemented in Kezilahabi's fiction which challenges both the epistemology and the ontology of realism. Reality is not as we assume it is; it can be otherwise; and we have no way to know how it is anyway. Already the opening passages of Nagona relativize the narrator's access to reality:

Yaelekea ilikuwa jioni, maana kulikuwa na mwanga hafifu wa kidhahabu humo bondeni nilimokuwa. Sikumbuki kuona jua na sikumbuki kuona mtu mwingine karibu nami. Labda maluweweluwe na usahaulifu ndio ulionifikisha hapa. Si mbali sana na mahali nilipojikuta niliona mto. ... Nilijikuta natembea kuelekea usawa wa mto huo. Nilihisi kuwa nilikuwa nikielekea unakotoka. (Nagona 1$)$

It was probably evening, because there was a weak golden light in the valley where I was. I do not remember seeing the light and I do not remember seeing anyone next to me. Maybe I was brought here by drowsiness and forgetting. Not far from where I found myself I saw a river. ... I found myself walking towards the surface of that river. I felt that I was going towards where it originated.

Epistemological distinctions are blurred, and the narrator is employing a probabilistic logic: he is probably in such and such place and it is probably such and such time. The text also shows the existential situation of the character, with all its contingency and resistance to human influence: he 
This is the version of the article accepted for publication in Research in African Literatures published by Indiana University Press: http://www.jstor.org/journal/reseafrilite

Accepted version downloaded from SOAS Research Online: http://eprints.soas.ac.uk/22865/

finds himself in a place, not knowing where he is and how he got there nor what time of the day it is.

He can only make conjectures about his whereabouts and about the time. The source of that knowledge is pure impression and feeling: "Nilihisi kuwa nilikuwa nikielekea. . .." 'I felt that I was heading. ...' Balancing the probabilities of his current state, the narrator also lacks the context: he does not know where he is currently situated within a broader sequence of his life's events: "Kama huo ndio ulikuwa mwanzo wa safari yangu, sina hakika. Lakini nilijikuta nimechoka." "Whether this was the beginning of my journey, I am not sure. But I found myself tired.' (Nagona 1). To make things even more complicated, the perceptions of the narrator are not congruent with one another: audial perceptions are not matched with visual ones: "[N]ilisikia mtu akikohoa. . . . nikaangalia huku na huko. Hapakuwa na mtu! [N]ilisikia nyayo za mtu akitembea nyuma yangu. . . . Nyuma, sikuona mtu!" 'I heard someone coughing. . . . I looked around me. There was no one! I heard someone walking behind me. ... Behind, I could not see anyone!' (Nagona 1).

The character is physically assaulted by a person he cannot see and escape, he is crawling on his knees and hears the laughter of invisible people and even trees, until he faints from exhaustion and pain. The fainting--the blacking out of consciousness--effectuates a shift in time and space; upon coming to senses, the narrator, again, does not know where he is and he can only guess the time: "Yaelekea ilikuwa asubuhi nilipozinduka." 'It was probably morning when I woke up.' (Nagona 1). His experience is entirely disconnected from the state he was in before he fainted.

A striking feature of Kezilahabi's prose in this passage is the frequent use of words derived from the verb kuelekea "to move in the direction of, to go towards." This verb occurs again and again in impersonal forms which function like adverbs, such as yaelekea "probably"; in the infinitive, having the meaning of a preposition, kuelekea "towards"; and in personal forms, such as "nilikuwa nikielekea unakotoka" 'I was moving towards where [the river] originated.' The verb indicates, on the one hand, spatial approximation, as in this last example; on the other hand, it is an expression of epistemological modality: the state of affairs is probably as described; the description approximates 
This is the version of the article accepted for publication in Research in African Literatures published by Indiana University Press: http://www.jstor.org/journal/reseafrilite

Accepted version downloaded from SOAS Research Online: http://eprints.soas.ac.uk/22865/

the actual situation. This use of the derivatives of kuelekea yields a very impressionistic, probabilistic description--a fluid, intangible representation of the depicted reality. On top of this, Kezilahabi's frequent use of compound verbal forms, which allow for a more precise expression of actions in terms of their completion (perfective) or processuality (imperfective), and more specifically his employment of the imperfective forms in this passage, adds to the protean, flowing nature of the depiction.

Another prominent characteristic of Kezilahabi's language in this passage is the frequency of derivatives of kustuka "to startle, to be surprised" and kujikuta "to find oneself," as well as of verbs of perception (kusikia "to hear"; kuona "to see," both often in the reflexive form, such as kujiona, literally "to see oneself, to feel"), of feeling (kuhisi "to feel") and of thinking (kufikiri "to think," kukumbuka "to remember"). Kezilahabi uses these to paint a vivid picture of the mental states of a person unsure about the circumstances of his existence and engulfed within incoherent, yet very intense, even painful impressions and perceptions. These passages are a prelude to even more puzzling occurrences which are to come and which culminate in the destruction of the "old world" (Mezger 77) during the Ngoma Kuu ("Big Dance"), when a chaotic dance overrides a dancing performance and brings about the death of a large part of humanity. This then leads to a rebirth in the construction of a "new world" (Mezger 81) at the end of Mzingile. The epistemological shattering presented in Nagona flips over into a proposal of a new epistemology, expressed in a new language:

"Sasa nafikiri yafaa tuanzishe lugha mpya," nilitoa wazo.

"Nami pia nimekuwa nikifikiria wazo hilo. Tutahitaji lugha ambayo haina cha Mtu na Kitu."

“Yafaa pia lugha hiyo isiwe na maneno kama 'nyuklia' au 'vita'. Tutaunda lugha ambayo msingi wake ni kuwako.” (Mzingile 69)

"Now, I think we should create a new language," I voiced a thought. 
This is the version of the article accepted for publication in Research in African Literatures published by Indiana University Press: http://www.jstor.org/journal/reseafrilite

Accepted version downloaded from SOAS Research Online: http://eprints.soas.ac.uk/22865/

"I have been thinking of that, too. We will need a language that does not contain the issue of Man and Thing."

“This language should also not contain words like 'nuclear' and 'war.' We shall create a language whose foundation is being."

This "language" expresses a new way of thinking which transcends the division of reality into the knowing subject and the known object. This fictional representation is consonant with the project theorized by Kezilahabi in his doctoral thesis, where he explicitly criticizes "the tragic epistemology of Western man" (“African" 219) based on "the categories of Subject/Object" (215). This is a philosophical utopia; a projection of a holistic epistemology. The future world is an implementation of Kezilahabi's philosophy which strives to propose a harmonious way of life based on "being" (“African” 219).

The destruction of the "old world" is paralleled in a disruption of literary realism by means of a radical narrative disarrangement. Chapters do not follow chronologically and the sequence and logic of the meandering plot remain unclear. Spatial contiguity is disturbed. Characters move in a disconnected way through time and space and they are prone to metamorphoses between humans and animals and to shifts in personal identity and unity. This stylistic experimentation results in a multilayered discontinuity and derangement of textual cohesion whereby textual incongruity effectuates, on the thematic level, a dissolution of ontological boundaries and epistemological blurriness.

But this also leads to a "rebirth" in terms of literary theory. The epistemology that does not separate between subject and object corresponds to a literature that does not distinguish between itself and reality. This finds expression in Kezilahabi's insistence on an "ontological reading" of literature in place of literature being a representation of the actual world. The literary world is not in a mimetic relationship with the real world; therefore literature cannot be projecting a possibility of the real world (as realist writing purports to do). Language and literature are not a representation, 
This is the version of the article accepted for publication in Research in African Literatures published by Indiana University Press: http://www.jstor.org/journal/reseafrilite

Accepted version downloaded from SOAS Research Online: http://eprints.soas.ac.uk/22865/

they are "it"; they are reality itself. As Gaudioso says, "la letteratura . . . non deve imitare la realtà, non deve rappresentarla, ma esserla" 'literature should not imitate reality, represent it, but be it' (162).

The world projected in Nagona and Mzingile is not a representation of the actual world and also not an allegory of the actual world. While the works are allegorical in places (for example, the dancing parade that introduces the global destruction), the key to their meaning is an ontological reading. What is the nature of the "future" world projected in Mzingile if read ontologically?

Kezilahabi is not writing the possible, if understood as a possibility of the actual world. This would mean that the duality between literature and representation is maintained. He is also not writing the future of the actual world, because that would, again, keep intact the view of literature as a representation of the actual world. He is therefore, rather than projecting the future or the possible of the actual world, giving another ontological status to "the possible" or "the future." Again, for Kezilahabi the future is not "possible," i.e. something ontologically distinct from an "actually existing" present, from the status quo. This derives from his insistence on the identity of "being" and "becoming" (Kezilahabi, "African" 124); the future "is" in the same way as the present, it is equally "real." He is therefore not exploring possibilities of a future world; he is "writing the future," but not the future of the actual world, but the future of a conceptual world he has himself constructed.

Kezilahabi's literary world in Nagona and Mzingile shares certain concepts with the actual world. These concepts are the philosophical ones. Kezilahabi is not inserting philosophers' names, the titles of philosophical works or concepts into his writing to "defamiliarize" his language, but to establish the nexus points that make his writing relevant to the actual world. While "everyday language" yields a description of the fictional world, these "unfamiliar concepts" are links to Kezilahabi the real person and to Kezilahabi the philosopher in the actual world. These concepts are of course not open to any allegorical reading but necessitate an ontological reading: Kezilahabi is simply writing his philosophy. In a fictional setting Kezilahabi can model an ideal philosophical 
This is the version of the article accepted for publication in Research in African Literatures published by Indiana University Press: http://www.jstor.org/journal/reseafrilite

Accepted version downloaded from SOAS Research Online: http://eprints.soas.ac.uk/22865/

world. The concluding passages of Mzingile, therefore, describe a "conceptual future": a possible (and desirable) conceptual development from a current philosophical constellation.

The editors of the recent Dunia Yao volume maintain that Swahili novels "differently from the futurist, utopian writings of the diaspora ... are utterly dystopian, drawing the future of the postcolony in dark colours" (Vierke and Greven 8). Admittedly, the futuristic optimism in Kezilahabi's writings is somewhat dampened through the puzzling conclusion of Mzingile which seems to be skeptical to the philosophical rebirth: mzee, the God figure in the novel, reappears and climbs on top of a mountain with Marx's Das Kapital on his back. This seems to be a return of the power structures of the old world (religion) coupled with Marx's teachings; or perhaps it means that Marxism has become the religion of the new world, inhabiting the habitual posts of power (God and his position on the mountain). Reminiscent of Sisyphus rolling a boulder on top of a mountain only to see it roll down again once he reaches the top, God climbing--again--on his mountain, dragging Das Kapital, is a powerful image of the "absurdity" (Jelpke) and "futility" (Tarrant) of the effort to remove divinity from the "hub" (Tarrant) of human existence. Yet, the "brave new world" outlined in the concluding passages of Mzingile is reinvigorating and its philosophical project continues inspiring Kezilahabi’s fans--like the author of this article--to break their heads about it.

A similar renewal of the world is also described in William Mkufya's Ziraili na Zirani, a novel where philosophy has an equally "fundamental role” (De Giuli 93). An elaborate epistemology of cognitive relativism, and an affirmation of multiple realms of reality being in existence simultaneously, is developed in the novel through a sophisticated handling of genre (use of poetry in a prose narrative), and the concluding passages of the novel are, literally, a testing of possibilities for a new world. It takes place on the thematic level in the scenes where angels are projecting the creation of new world. They have been tasked "to create a being having the best possible combination of qualities to go with free will" (Rettová, Afrophone Philosophies 235). Like Kezilahabi, Mkufya does not hide his "real-world referents" behind fictional names: Marx, Voltaire 
This is the version of the article accepted for publication in Research in African Literatures published by Indiana University Press: http://www.jstor.org/journal/reseafrilite

Accepted version downloaded from SOAS Research Online: http://eprints.soas.ac.uk/22865/

or Schopenhauer figure in his novel. The meaning of their insertion in the text is not to be decoded through an allegorical reading. These thinkers and concepts are not metaphors for something else but themselves, actual philosophers and ideas with which the readers have to deal in reality. In other words, they have to be taken "ontologically." Mkufya's narrative itself theorizes the mechanism of the transposition of the hell and heaven events into the "actual world": the events in heaven and hell are "really" taking place as a battle of ideas in the minds of living people. These "living people" are the inhabitants of the fictional world in the novel, but equally Mkufya's readers, i.e. people in the extra-literary "actual world."

Both Kezilahabi and Mkufya are describing new worlds constructed in the wake of global catastrophes which destroyed the entire humanity and the world. In Mkufya's case, this destruction takes place on several planes: a nuclear explosion on earth, corresponding to a destruction of representations of divinity in heaven and to humanity's adoption of atheism on the level of ideas. Kezilahabi's destruction takes the form of a dance parade during which the philosophies of past centuries, represented by Aristotle, Freud, and Marx, are overridden by the "dance of chaos" of a group of self-proclaimed madmen, interpreted by Khamis as the "nameless group of the badly dressed and half-naked dancers representing African Being" ("Fabulation" 129). Also here one finds significant parallels between Kezilahabi's fiction and his philosophy. The novelistic apocalypse is paralleled in his theoretical writings, which insist that "African literary criticism has to take a destructive rather than a deconstructive stand vis-à-vis the Western philosophy of value and representation" (“African” 4) and which, indeed, effectuate a large-scale demolition and reconstruction of the very foundations of African philosophy. The destruction and chaos is never self-purposive for these two novelists; the apocalypse lays the foundations of a new, better world. It is the act of wiping clean the tabula rasa, in order to "write the future and the possible."

The conceptual futurism of Nagona, Mzingile, and Ziraili na Zirani stages planetary destructions to erect new worlds, testing the limits of the possible. Mkufya projects a morally just 
This is the version of the article accepted for publication in Research in African Literatures published by Indiana University Press: http://www.jstor.org/journal/reseafrilite

Accepted version downloaded from SOAS Research Online: http://eprints.soas.ac.uk/22865/

future, a creation that would be on a par with the great responsibility of self-conscious beings' having free will. Kezilahabi develops a philosophical future which follows upon a philosophical destruction. Through his request of onto-criticism, Kezilahabi claims a radically unmimetic project: his writing is not imitating anything; it is an expression of ideas themselves. Both Kezilahabi and Mkufya prioritize the epistemological aspect of imagining ailleurs. An elaborate game with multiple epistemologies features prominently in the Shona novels of Masimba Musodza, which combine the genres of sci-fi and horror.

\section{EPISTEMOLOGY OF AWE}

The plot of Musodza's MunaHacha Maive Nei? is based on the spillage of growth hormones into the river Hacha. The chemicals themselves are the product of illegal biological experiments commissioned by multinational corporations, represented in the novel by the American Jeffrey Keegan, who wants to develop genetically mutated products and sell them in Africa. On account of a road accident, the chemicals spill into the environment and penetrate the water system through the river Hacha. A teenage girl raped by her uncle delivers a baby close to a dam on this river and she tosses the baby into the dam. Having tasted human flesh, carnivorous fish in the river now consume the growth hormones leaked from the biological experiments, grow to monstrous proportions and start attacking humans.

The novel uses descriptive realism to depict what is happening. A chief stylistic device, drawing on the horror genre, is suspense. It is a cognitive as well as literary device to make space for that which transcends the limits of understanding and of the known world. The novel craftily builds up suspense from its first chapters. After introducing the main characters, the heroine Taru, the villain Keegan, and the powerful river, connections are suggested between five unrelated occurrences: 
This is the version of the article accepted for publication in Research in African Literatures published by Indiana University Press: http://www.jstor.org/journal/reseafrilite

Accepted version downloaded from SOAS Research Online: http://eprints.soas.ac.uk/22865/

Pane zviitiko zvishanu zvakaitika munzvimbo dzakasiyana, misi yakasiyana uye nemutoo wakasiyana zvekuti hapana aikwanisa kufembera kuti zviitiko zvese izvi zvingave zvakabatanidzana nyangwe dai munhu iyeye ainge anyatso rondedzerwa zvizere nezvazvo.

There were five occurrences which happened in different places, on different days and in different manners, so that no one could guess that all these events could be connected even if that person were told their details.

While some of these are seemingly innocent events, some have a foreboding of what lies ahead: the Nhemwa family are encircled by soldiers when they try to help the driver of a truck who had an accident; they see a bottle of a chemical called "Mukadziusaende Lot 04/09" (mukadziusaende means “woman, don't go") and are warned not to speak about what they've seen. In another place, two boys find a rabbit the size of a goat which scares even the dogs and dies soon after on account of its skeleton being unable to support its weight.

Suspense is a stylistic means to create space for the unknown. The narrative describes the signs of the presence of the unknown, its effects, but it itself is never in the focus. For instance, the old Karoro is followed by the sounds of breathing and steps of a being which he cannot see. The breathing of that being is likened to mhuka huru yaneta "an exhausted large animal" (138) or to munhu ave kufa "a dying human being" (138). This mysterious encounter continues on several pages and ends in Karoro's reaching home without ever seeing the gasping being that was following him.

The unknown is then approached through two explanatory models. The local understanding works with supernatural forces. The region is believed to have a feared nzvimbo inoyera, "a taboo place." Taru, as a fearless and rationalistic town girl, convinces her friend Julius to go and visit that 
This is the version of the article accepted for publication in Research in African Literatures published by Indiana University Press: http://www.jstor.org/journal/reseafrilite

Accepted version downloaded from SOAS Research Online: http://eprints.soas.ac.uk/22865/

place. It's a place on the river bank where grass, trees, and plants have grown to incredible proportions. The children speculate about somebody disposing of fertilizer in that soil, but they realize that no fertilizer could account for such astounding growth. While they are there, Julius loses his iPod. He goes to retrieve it later on, falls into the river and disappears. The locals speak of him being taken away by a mermaid:

Sezvakanga zvarondedzerwa nevakomana vakatanga kutaura naGabi, Julius akange aenda kusango rinoyera achitsvaga kaaipodhi kake. Vengai paakateera, akasvikowana Julius awira munaHacha, achiridza mhere, achibhaguja, ndokubva anyudzwa nenjuzu.

As it was told by the youths who first spoke to Gabi, Julius had gone to the taboo forest looking for his iPod. When Vengai followed him, he found Julius had fallen into the Hacha, was screaming and struggling in the water, and then he was pulled under water by the mermaid. (165)

The excessive growth is attributed to witchcraft and the disasters are interpreted as the activity of water spirits. This local understanding is in clash with the scientific explanation, that is, the changes in the flora and the fauna are the effect of artificially developed growth hormones and genetic mutations.

The rationalistic epistemology of science is opposed to a local epistemology relying on myth and religious belief. The scientific epistemology is represented in the novel by both the foreign agents, Keegan and his clique, and local police and journalists, such as Gabi from the paper Nhariro ("Watchtower"), who are skeptical of the supernatural interpretations. Hearing about "mermaids," Gabi asks about the evidence supporting these claims: 
This is the version of the article accepted for publication in Research in African Literatures published by Indiana University Press: http://www.jstor.org/journal/reseafrilite

Accepted version downloaded from SOAS Research Online: http://eprints.soas.ac.uk/22865/

“Zvino, Vengai wacho abva abatwa nehope. Paazopwatika, Juli akange asisimo mumba, ndobva aziva kuti anga aenda kusango riya rinoyera. Vengai paakasvikako, Juli akange ari mudziva, ndokubva atorwa nenjuzu."

"Saka, babamunini, munoreva imi kuti Vengai uyu aona njuzu yacho nemeso ake here?" Gabi akabvunza. (164)

"Now, as for Vengai, he fell asleep. When he woke up, Juli was no longer in the house, and then he knew that he had gone to the taboo forest. When Vengai arrived there, Juli was in the lake and then he was taken by the mermaid."

"So, uncle, are you saying that Vengai has seen the mermaid herself with his own eyes?" Gabi asked.

However, it soon becomes clear that the matter itself escapes the understanding of both of these epistemologies: the events are incomprehensible not only to local beliefs but also to science. While science launched these catastrophes, it is no longer able to explain them, let alone provide a solution to them. Things have gone out of limits and unpredictable, qualitatively new things are happening. Unknown monsters have emerged and unspeakable events are taking place. The horror of the activities of the mutated animals transcends the limits of scientific understanding and, for science also, is a leap into the unknown. Narratives of a similar occurrence of seemingly banal and everyday actions getting out of hand and culminating in unspeakable horrors can be found in Swahili novels such as Ruhumbika's Janga Sugu la Wazawa and Mbogo's Vipuli vya Figo. Both are exaggerations of existent practices of mutilating people: getting body parts for magical potions in one case and for transplants in the other.

The epistemology of awe is thus equally valid for all: an explanation based on native religious spirituality and a scientific explanation are both wrong and both fail. Such failure of 
This is the version of the article accepted for publication in Research in African Literatures published by Indiana University Press: http://www.jstor.org/journal/reseafrilite

Accepted version downloaded from SOAS Research Online: http://eprints.soas.ac.uk/22865/

available explanatory models to account for what is happening is the very principle of horror stories; it makes space for an epistemology of awe whose object is "the unknown." A new reality is emerging from the space vacated by existing explanatory paradigms and it is making itself palpable to people who completely lack the conceptual means to grasp it and talk about it.

The Shona sci-fi novel writes about the possible through this epistemology of awe. The possible is conceptualized here as the unknown and approached through a simultaneous demonstration of its effects and a staking out of what it is not; it asserts again and again its nonidentity with any of its given representations. Such a negative description is similar to the procedures employed by negative theology: the horror narrative builds a space for that which transcends available epistemologies and their explanatory paradigms. It is an epistemology of being in awe of something that transcends one's understanding. The possible, conceptualized as the unknown, is located in the space vacated by the receding explanatory models which both fail in the face of the new reality. This empty space is textually constructed through the device of suspense. The unknown is eventually revealed in the narrative and the epistemology of awe is resolved in a viable explanatory model. But it is the suspense built throughout the narrative until the moment of resolution that is the space for the possible.

Shona science fiction concurs with contemporary Anglophone African science fiction in its emphasis on ecological issues, but also in its reliance on conspiracy theories, where the Global North maintains its grip on Africa through underhand practices of illegal trade, commercializing of development aid, or, as in this case, dangerous and detrimental scientific experiments. Africa becomes the victim of the wickedness and cynicism of multinational corporations and local issues and disasters have an explanation in illicit practices happening on a massive, global scale. Behind the known and obvious world, there is another, horrid reality affecting the planet and the entire humanity. At the same time, Africa's indigenous resources of knowledge and wisdom may sometimes become the source of help and planetary healing. ${ }^{2}$ 
This is the version of the article accepted for publication in Research in African Literatures published by Indiana University Press: http://www.jstor.org/journal/reseafrilite

Accepted version downloaded from SOAS Research Online: http://eprints.soas.ac.uk/22865/

The Shona sci-fi cum horror (MunaHacha Maive Nei?) approaches the possible negatively, through suspense which creates space for the unknown. The possible, which in sci-fi is projected into outer space and in futurism into a future time, is projected here into the unknown, into that which escapes existing explanatory models. The possible is, as it were, folded into the habitual world. It is another realm co-existing with the world as accessed, on the one hand, through the positivistic epistemology of science and, on the other hand, through the epistemology of religious beliefs and traditions. Another, new reality is arising in the midst of the familiar and mundane. The possible--the ailleurs--is conceptualized as the unknown and accessed through the "epistemology of awe."

\section{CONCLUSION: WRITING THE FUTURE AND THE POSSIBLE}

This article has shown the different possibilities to imagine and "write" the possible and the future in Shona and Swahili novels. It is significant that these novels are Afrophone, connected within and contributing to ongoing discussions in their respective languages. Their sheer existence refutes the tendency to associate African languages and Afrophone literatures with "tradition," understood as a mere fossilized relic of the past. In his overview of Shona speculative fiction, Musodza critically deals with the view that "ChiShona is the language for expressing archaic ideas bound to an archaic way of life, such that anyone seeking to enter the modern world will have to leave behind this language.” (“A Foundation" no page). The novels discussed here show that literatures in African languages speculate about advanced technology or time travel, but that they are also actively engaged in contemporary literary and philosophical discussions within and beyond their cultures of origin and able to "enrich post-colonial theoretical debates on literature" (Tchokothe, "Globalectical" $31)$.

The Swahili and Shona novels covered here construct alternative, possible worlds in different ways: they project them into the future or into outer space; fold them into our present world; or 
This is the version of the article accepted for publication in Research in African Literatures published by Indiana University Press: http://www.jstor.org/journal/reseafrilite

Accepted version downloaded from SOAS Research Online: http://eprints.soas.ac.uk/22865/

develop them conceptually through philosophical speculation. These are projections of social and political critiques and ideals; philosophical and moral ones; or they remain on the level of indeterminacy and mystery. It has been emphasized here that these novels need to be read through the prism of futuristic imagination, underscoring their capacity to project an ailleurs; in short, they need to be reclassified and reinterpreted under the labels of sci-fi and Afrofuturism.

Afrophone sci-fi and futurist literature constitutes a powerful counter-discourse to the traditionalistic images of the African continent. It effectuates a $180^{\circ}$ turn away from the past-oriented imagination of African nationalists and constitutes a powerful rejection of "philosophies of origins" so criticized by Kezilahabi (“African” 357) for having an overbearing influence on Africa. As Okoth resolutely states: "In a time where predictions of future developments have become such a valuable commodity, it is no longer enough to challenge power retrospectively as many philosophies of origin do" (Okoth 6).

\section{ENDNOTES}

${ }^{1}$ All translations, also of concepts and the names of novels and other works, are mine unless stated otherwise.

${ }^{2}$ A case in question is Ugandan writer and filmmaker Dilman Dila's short story "Leafy Man," where "herbalism and traditional ecological knowledge" (Bould, "If Colonialism" no page) is effective to remedy "the after-effects of a corporate bioengineering experiment gone wrong" (Kamo no page) which ends up producing dangerous genetically mutated mosquitoes.

\section{WORKS CITED}

Aiello Traore, Flavia. "Postmodernism As Seen through the Swahili Novel: A Reading of Babu Alipofufuka and Dunia Yao by Said Ahmed Mohamed. Journal of African Cultural Studies 27.1 (2015): 20-29. Special Issue: Literatures in African Languages. Ed. Sara Marzagora. Print.

Barthes, Roland. "The Reality Effect.” The Rustle of Language. Trans. Richard Howard. Berkeley and Los Angeles: University of California Press, 1989. 141-148. Print. 
This is the version of the article accepted for publication in Research in African Literatures published by Indiana University Press: http://www.jstor.org/journal/reseafrilite

Accepted version downloaded from SOAS Research Online: http://eprints.soas.ac.uk/22865/

Beaumont, Matthew (ed.). A Concise Companion to Realism. Malden, Oxford, Chichester: WileyBlackwell, 2010, first edition 2007 as Adventures in Realism. Print.

Bertoncini-Zúbková, Elena. “Kenyan Literary Kiswahili.” Afrikanistische Arbeitspapiere 61 (1999): 45-58. Print.

Bertoncini Zúbková, Elena. "When Grandfather Came to Life Again: Said Ahmed Mohamed’s New Novel beyond Realism.” Afrikanistische Arbeitspapiere 72 (Swahili Forum 9) (2002): 25-33. http://www.qucosa.de/fileadmin/data/qucosa/documents/9134/9_04_bertoncini.pdf.

Bertoncini-Zúbková, Elena, Mikhail D. Gromov, Said A. M. Khamis, and Kyallo W. Wamitila, K. W. Outline of Swahili Literature: Prose Fiction and Drama. Leiden and Boston: E. J. Brill, 2009 (first edition 1989). Print.

Bould, Mark. “Africa SF: Introduction.” Paradoxa 25 - Africa SF (2013): 7-15.

Bould, Mark. "If Colonialism Was The Apocalypse, What Comes Next? Mark Bould on Terra Incognita: New Short Speculative Stories from Africa and A Killing in the Sun." Los Angeles Review of Books (2015). https://lareviewofbooks.org/review/if-colonialism-was-theapocalypse-what-comes-next-dilman-dila.

Bould, Mark. “African Science Fiction 101.”SFRA Review 311 (2015): 11-18. Web. 23 March 2016. https://sfra.wildapricot.org/resources/sfra-review/311.pdf.

Chirere, Memory. "Ignatius Mabasa's Mapenzi and Innovation in the Shona Novel: The Zimbabwean Response." Beyond the Language Issue: The Production, Mediation and Reception of Creative Writing in African Languages. Ed. Anja Oed \& Uta Reuster-Jahn. Cologne: Rüdiger Köppe Verlag, 2008. 221-225. Print.

Coughlin, David. "Dancing in Their Own Style? Philosophy in Euphrase Kezilahabi’s Nagona/Mzingile and the Uses of Postcolonial Discourse in its Analysis." Journal of African Cultural Studies 28.2 (2016): 196-208. Special Issue: African Philosophy. Ed. Alena Rettová. DOI: 10.1080/13696815.2015.1092080, published online: 12 Oct 2015. Web. 23 March 2016.

Cornillie, Frederik. "Postcolonial Literary Theory and the Spectre of Realism: An Evaluation of the Current Position of the Realist Novel in Postcolonial Theory and Criticism, with a Case Study of Rohinton Mistry's Fiction.” Unpublished M.A. Thesis, Katholieke Universiteit Leuven, 2005. Web. 23 March 2016.

http://users.telenet.be/frederikcornillie/pub/PCTheoryAndRealism.pdf. 
This is the version of the article accepted for publication in Research in African Literatures published by Indiana University Press: http://www.jstor.org/journal/reseafrilite

Accepted version downloaded from SOAS Research Online: http://eprints.soas.ac.uk/22865/

Dembo, Umaru. Tauraruwa Mai Wutsiya. Zaria: The Northern Nigerian Publishing Company, 1971. Print.

De Giuli, Lou Akusua. “Ziraili na Zirani, A Philosophical Analysis.” Swahili Forum 19 (2012): 8895. Print.

Diegner, Lutz. "Intertextuality in the Contemporary Swahili novel: Euphrase Kezilahabi’s Nagona and William E. Mkufya's Ziraili na Zirani.” Swahili Forum 12 (2005): 25-35. http://www.qucosa.de/fileadmin/data/qucosa/documents/9122/12_03_Diegner.pdf.

Diegner, Lutz. "Bwanamvinyo, Protean Nyerere, and the Battleground of Ideas: The Contribution of Swahili Novels to East African Intellectual History." African Thoughts on Colonial and NeoColonial Worlds: Facets of an Intellectual History of Africa. Ed. Arno Sonderegger. Berlin: Neofelis Verlag, 2015. Print.

Eshun, Kodwo. "Further Considerations of Afrofuturism." CR: The New Centennial Review 3.2 (2003): 287-302. Print.

Furniss, Graham. Poetry, Prose and Popular Culture in Hausa. Washington Institution Press: Washington, D. C., 1996.

Garnier, Xavier. The Swahili Novel: Challenging the Idea of "Minor Literature." Xavier Garnier. Translated by Rémi Tchokothe Armand and Frances Kennett. Woodbridge: James Currey, 2013. Print.

Gaudioso, Roberto. "Il linguaggio del dolore e della libertà: Il poeta swahili Euphrase Kezilahabi tra ricerca estetica e impegno sociale." Smerilliana: luogo di civiltà poetiche 18 (2015): 143-176. Print.

Gromov, Mikhail D. “Nagona and Mzingile--Novel, Tale or Parable?” Swahili Forum 5 (1998): $73-$ 78. Print.

Gromov, Mikhail D. "Postmodernistic Elements in Recent Swahili Novels.” Nairobi Journal of Literature 2 (2004): 28-36. Print.

Gromov, Mikhail D. "Visions of the Future in the 'New' Swahili Novel: Hope in Desperation?" Tydskrif vir letterkunde 51.2 (2014): 40-51. Web. 23 March 2016. http://www.letterkunde.up.ac.za/argief/51_2/04\%20Gromov\%2003\%20WEB.pdf.

Gromov, Mikhail D. “'Local Achievement' or 'External Influence'? Intertextuality and Political Satire in the 'New' Swahili Novel in Kenya." Dunia Yao: Utopia/Dystopia in Swahili Fiction. Ed. Clarissa Vierke and Katharina Greven, Cologne: Rüdiger Köppe. 57-71. Print. 
This is the version of the article accepted for publication in Research in African Literatures published by Indiana University Press: http://www.jstor.org/journal/reseafrilite

Accepted version downloaded from SOAS Research Online: http://eprints.soas.ac.uk/22865/

Hegel, Georg Wilhelm Friedrich. The Philosophy of History. With prefaces by Charles Hegel and the translator, J. Sibree, M.A.. Kitchener: Batoche Books, 2001, first edition in German 1837.

Jelpke, Tom. “Absurditea: The Absurd and 'The Unity of Being' in Euphrase Kezilahabi's 'Chai ya jioni'." Unpublished conference presentation at the 29th Swahili Colloquium, Bayreuth, 6th8th May 2016.

Kahari, George. The Rise of the Shona Novel: A Study in Development, 1890-1984. Gweru: Mambo Press, 1997, first edition 1990. Print.

Kamo, K. “A Killing in the Sun by Dilman Dila.” Book Review. Web. 23 March 2016. http://www.strangehorizons.com/reviews/2015/01/a_killing_in_th.shtml.

Khamis, Said A. M. “Classicism in Shaaban Robert's Utopian Novel, Kusadikika.” Research in African Literatures 32.1 (2001): 47-65. Print.

Khamis, Said A. M. "Fabulation and Politics of the 90s in Kezilahabi's Novel Nagona." African Language Literature in the Political Context of the 1990s. Ed. Charles Bodunde. Bayreuth African Studies 65. Bayreuth: Eckhard Breitinger, 2001. 119-133. Print.

Khamis, Said A. M. "Fragmentation, Orality and Magic Realism in Kezilahabi's Novel Nagona." Nordic Journal of African Studies 12.1 (2003): 78-91. Web. 23 March 2016. http://www.njas.helsinki.fi/pdf-files/vol12num1/khamis2.pdf.

Khamis, Said A. M. "Signs of New Features in the Swahili Novel." Research in African Literatures 36.1 (2005): 91-108. Print.

Kezilahabi, Euphrase. “African Philosophy and the Problem of Literary Interpretation.” Unpublished Ph.D. dissertation, University of Wisconsin (Madison), 1985.

Kezilahabi, Euphrase. Nagona. Dar es Salaam: Dar es Salaam University Press, 1990. Print. Kezilahabi, Euphrase. Mzingile. Dar es Salaam: Dar es Salaam University Press, 1991. Print. Lanfranchi, Benedetta. "Daring to Be Destructive: Euphrase Kezilahabi’s Onto-criticism.” Swahili Forum 19 (2012), 72-87. Print.

Leonard, Elisabeth Anne. "Race and Ethnicity in Science Fiction." The Cambridge Companion to Science Fiction. Ed. Edward James and Farah Mendlesohn. Cambridge: Cambridge University Press, 2003. Print.

Mbiti, John S. African Religions \& Philosophy. Oxford: Heinemann Educational Publishers, 1969. Print. 
This is the version of the article accepted for publication in Research in African Literatures published by Indiana University Press: http://www.jstor.org/journal/reseafrilite

Accepted version downloaded from SOAS Research Online: http://eprints.soas.ac.uk/22865/

Mezger, Sonja. "Roman Catholic Faith Represented in Kezilahabi’s Mzingile." Swahili Forum 9 (2002): 75-85. Print.

Mkangi, Katama. Walenisi. Nairobi et al.: East African Educational Publishers, 2003, first edition 1995. Print.

Mkufya, William E. Ziraili na Zirani. Dar es Salaam: Hekima Publishers, 1999. Print.

Mkufya, William E. "Mazungumzo na Lutz Diegner juu ya Riwaya ya Ziraili na Zirani." Swahili Forum 12 (2005): 37-62. Web. 23 March 2016.

http://www.qucosa.de/fileadmin/data/qucosa/documents/9826/12_04_Mkufya.pdf.

Mohamed, Said A. Babu Alipofufuka. Nairobi: Jomo Kenyatta Foundation, 2001. Print.

Mohamed, Said A. Dunia Yao. Oxford et al.: Oxford University Press, 2006. Print.

Moudileno, Lydie. “Magical Realism: ‘Arme miraculeuse’ for the African Novel?” Research in African Literatures 37.1 (2006): 28-41. Print.

Musodza, Masimba. MunaHacha Maive Nei? Gloucester: Diaspora Publishers, 2012. First edition 2011 Amazon Kindle. Print.

Musodza, Masimba. Shavi Rechikadzi Middlesbrough: Belontos Books, 2015. Print.

Musodza, Masimba. “Interview with Masimba Musodza.” Web. 23 March 2016.

https://www.facebook.com/MasimbaMusodzaAuthor/videos/10151750752385575/.

Musodza, Masimba. “A Foundation for Speculative Fiction in ChiShona.” Unpublished keynote speech at the Asixoxe--Let's Talk! SOAS and BIGSAS conference on African Philosophy, London, 28th-29th April 2016.

Mwangi, Jedidah Wanjiru. "Uhalisia na Uhalisiajabu katika Riwaya Mpya: Babu Alipofufuka (Said A.Mohammed) na Watu wa Gehenna (Tom Olali)." Unpublished M.A. Thesis, University of Nairobi, 2013. Web. 23 March 2016. http://erepository.uonbi.ac.ke/handle/11295/59715.

Okoth, Kevin Ochieng. "Creating Counterfutures: The Concept of Time in Afrofuturism."

Unpublished paper at the Asixoxe--Let's Talk! SOAS and BIGSAS conference on African Philosophy, London, 28th-29th April 2016.

Olali, Tom. Mafamba. Nairobi: Jomo Kenyatta Foundation, 2008. Print.

Olali, Tom. Watu wa Gehenna. Nairobi: Jomo Kenyatta Foundation, 2012. Print. 
This is the version of the article accepted for publication in Research in African Literatures published by Indiana University Press: http://www.jstor.org/journal/reseafrilite

Accepted version downloaded from SOAS Research Online: http://eprints.soas.ac.uk/22865/

Olali, Tom. "Some Say I'm a Dreamer, But My Style Is to Tell It As I See It.” Daily Nation 29th March 2014. Web. 23 March 2016. http://www.nation.co.ke/lifestyle/artculture/my-style-isto-tell-it-as-I-see-it/-/1954194/2262008/-/ty0e8pz/-/index.html.

Peterson, Alayne M. "Riders of the New Wave: The Feminist Science Fiction of Le Guin, Russ, and Tiptree." In Womanhood in Anglophone Literary Culture: Nineteen and Twentieth Century Perspectives. Ed. Robin Hammermann. Newcastle: Cambridge Scholars Publishing, 2007. 210-244. Print.

Piłaszewicz, Stanisław. "Literature in the Hausa Language." Literatures in African Languages: Theoretical Issues and Sample Surveys. Ed. B. W. Andrzejewski, S. Piłaszewicz \& W. Tyloch. Warszawa: Wiedza Powszechna \& Cambridge et al.: Cambridge University Press, 1985. 190-254. Print.

Rettová, Alena. Afrophone Philosophies: Reality and Challenge. Středokluky: Zdeněk Susa, 2007. Print.

Rettová, Alena. "Novel in African Languages." In Oxford History of the Novel in English, Volume 11: The Novel in Africa and the Caribbean since 1950. Ed. Simon Gikandi, New York: Oxford University Press, 2016. 71-86. (in press)

Robert, Shaaban. Kusadikika. Nchi Iliyo Angani. Nairobi et al.: Nelson, 1981, first edition 1951. Print.

Robert, Shaaban. Kufikirika. Nairobi et al.: Oxford University Press, 1983, first edition 1967. Print. Stephen. http://www.africa-news.eu/africans-abroad/africans-abroad/africans-in-uk/munahachamaive-nei-first-ever-science-fiction-novel-in-chishona.html. 2011. Web. 23 March 2016.

Tarrant, Duncan. "Faith and Futility in Mzingile." Unpublished conference presentation at the 29th Swahili Colloquium, Bayreuth, 6th-8th May 2016.

Tchokothe, Rémi Armand. Transgression in Swahili Narrative Fiction and Its Reception. Wien et al.: LIT Verlag, 2014. Print.

Tchokothe, Rémi Armand. "Globalectical Swahili Literature.” Journal of African Cultural Studies 27.1 (2015): 30-39. Special Issue: Literatures in African Languages. Ed. Sara Marzagora. Print.

Topan, Farouk. "Why Does a Swahili Writer Write? Euphoria, Pain, and Popular Aspirations in Swahili Literature." Research in African Literatures 37.3 (2006): 103-119. Print. 
This is the version of the article accepted for publication in Research in African Literatures published by Indiana University Press: http://www.jstor.org/journal/reseafrilite

Accepted version downloaded from SOAS Research Online: http://eprints.soas.ac.uk/22865/

Trésor de la langue française informatisé (The Digitized Treasury of the French Language). http://www.cnrtl.fr/definition/ailleurs. Web. 23 March 2016.

Vierke, Clarissa and Katharina Greven. "Introduction. Dunia Yao. Critical Visions of the Future in Swahili Fiction.” In Dunia Yao: Utopia/Dystopia in Swahili Fiction. Ed. Clarissa Vierke and Katharina Greven, Cologne: Rüdiger Köppe. 7-24. Print.

Vierke, Clarissa. “The ‘Unhomely’ City: A Literary Figuration in Swahili Dystopian Literature.” In Dunia Yao: Utopia/Dystopia in Swahili Fiction. Ed. Clarissa Vierke and Katharina Greven, Cologne: Rüdiger Köppe. 73-89. Print.

Wamitila, Kyallo W. "Nagona and Mzingile: Kezilahabi’s Metaphysics.” Kiswahili 54 (1991): 62-67. Print.

Wamitila, Kyallo W. "Contemptus Mundi and Carpe Diem Motifs in Kezilahabi’s Works.” Kiswahili 60 (1997): 15-24. Print.

Wamitila, Kyallo W. "Reading the Kenyan Swahili Prose Works: A Terra Incognita in Swahili Literature." Afrikanistische Arbeitspapiere 51 (1997): 117-125. Print.

Wamitila, Kyallo W. “A Philosophical Labyrinth: Tracing Two Critical Motifs in Kezilahabi’s Prose Works." Swahili Forum 5 (1997): 79-91. Print.

Wamitila, Kyallo W. “Unlocking Katama Mkangi's Walenisi. A Case of Parabolic Narrative?” Kiswahili 61 (1998): 83-93. Print.

Wamitila, Kyallo W. Uhakiki wa Fasihi. Misingi na Vipengele Vyake. Nairobi: Phoenix.

Wamitila, Kyallo W. Bina-Adamu! Nairobi: Phoenix Publishers, 2002. Print.

Wamitila, Kyallo W. Kamusi ya Fasihi: Istilahi na Nadharia. Nairobi: Focus Books, 2003. Print.

Wamitila, Kyallo W. Musaleo! Nairobi: Vide Muwa Publishers, 2004. Print.

Warnes, Christopher. "The Hermeneutics of Vagueness: Magical Realism in Current Literary Critical Discourse.” Journal of Postcolonial Writing 41.1 (2005): 1-13. Print.

Womack, Ytasha L. Afrofuturism. The World of Black Sci-Fi and Fantasy Culture. Chicago: Lawrence Hill Books, 2013. Print.

Yaszek, Lisa. “An Afrofuturist Reading of Ralph Ellison's Invisible Man.” Rethinking History 9.2-3 (2005): 297-313. Print. 
This is the version of the article accepted for publication in Research in African Literatures published by Indiana University Press: http://www.jstor.org/journal/reseafrilite

Accepted version downloaded from SOAS Research Online: http://eprints.soas.ac.uk/22865/

Yaszek, Lisa. "Race in Science Fiction: The Case of Afrofuturism and New Hollywood." In $A$ Virtual Introduction to Science Fiction. Ed. Lars Schmeink. 2013. 1-11. Web. 23 March 2016. <http://virtual-sf.com/?page_id=372>. 